\title{
The Two alun-alun of Malang (1930-1960)
}

\author{
Purnawan Basundoro
}

\section{Introduction}

Arguably the most prominent characteristic of a typical town in Java is the presence of an alun-alun or town square. In general an alun-alun is a large open space; ordinary citizens often think of it as a field in the centre of the town. In some cities the alun-alun takes the form of a square studded with shady trees. An alun-alun is usually imagined as the core of the Javanese town, in part because it typically forms the 'heart' of a whole network of streets. But more significantly, the alun-alun carries symbolic significance because, traditionally, it was located directly in front of the palace (kraton), or regional kabupaten, the traditional seats of Javanese power. The traditional model on which all such alun-alun drew and in terms of which they were imagined was the Kraton of Yogyakarta. This was located on an imaginary line, which connected the Southern Ocean, the southern alun-alun, the palace itself, the northern alun-alun, and Mount Merapi on a north-south axis.

In the traditional configuration, on one side of an alun-alun would stand the royal audience hall (siti hinggil) or the residence of the Regent (kabupaten). If we were to compare the palace or the residence of the bupati to a private house, the alun-alun would be its front and sometimes also its back yard. The discussion of the role of the alun-alun in the development of Javanese cities is, therefore, very important, because it formed the centre from which the development of a town was initiated.

People's views of the alun-alun are many and various. Traditionally a banyan tree planted on the alun-alun was associated with mystical powers, as for instance the two banyan trees exactly in the centre of the alun-alun in Yogyakarta and Surakarta. When one of the banyan trees in the middle of the alun-alun of Yogyakarta collapsed in 1989, many people grew anxious and interpreted the falling of the tree as an ominous sign. Shortly afterwards the ruler of Yogyakarta, Sri Sultan Hamengkubuwono IX, died and his death reinforced the belief of many people in the magical properties of the tree.

Among modern people, whose historical appreciation of the Javanese town may not be very strong, an alun-alun may simply be understood as a public space which can be used as a playground, as a place for dating, practising sports, selling things, even for herding cattle or as a place for conducting ceremonies on such special days, such as the celebration of Indonesian

(C) PURNAWAN BASUNDORO, 2015 | DOI 10.1163/9789004280724_012

This is an open access chapter distributed under the terms of the Creative Commons Attribution-

Noncommercial 3.0 Unported (CC-BY-NC 3.0) License. 
Independence. For Muslim citizens, it can also be the large space needed to hold Eid prayers, such as those observed at the end of the Ramadan.

A glimpse back in history shows that the alun-alun is definitely not just an empty space, which can be used for various profane activities. At certain periods in the past, it has been a potent symbol pregnant with meaning. The most general and powerful significance associated with the alun-alun has been as a formal space closely related to official (royal) ceremonies, a function which it developed during the periods of traditional kingdoms. There is also evidence that the alun-alun has had spiritual meaning. This connection with royal spiritual power is drawn from the physical proximity of the alun-alun to the residence of a ruler. Even in the Muslim state of Mataram - in contravention of the strict monotheism of Islam - the alun-alun was one of the elements used in the cult of the glorification of the king (Moertono 1985:84).

The alun-alun has also been a meeting ground for a ruler and his subjects. It is on the alun-alun that all the king's guests had to wait before being admitted into his presence (seba). Therefore, the alun-alun is also called the paseban. The common people, who are the kawula or citizens of the kingdom, also think of the alun-alun as being the symbol of democracy because at this place they can stage a protest against the bureaucratic apparatus of the kingdom or even against the ruler himself. Such protests took the form of a pepe: that is, the practice of lying or sitting in the full sun until their ruler approached them.

Because it was a space imbued with special significance in terms of the concept of Javanese power, alun-alun attracted the attention of the Dutch colonial government when it sought to establish its authority in Java. This newcomer also wanted to use the alun-alun as a representation of its recently won power in Javanese territory. It therefore signified its ascent to power by symbolically appropriating this public space and building the accommodation for the Dutch Resident or Assistent-Resident on the alun-alun opposite the palace or the Regent's residence. The most obvious example of this is in Yogyakarta, where the house of the Dutch Resident (nowadays known as Loji Kebon) and the outward and visible sign of the Dutch military presence, Fort Vredenburg (or Loji Besar), were built exactly opposite the palace. The erection of these colonial buildings on the alun-alun could be interpreted as a symbolic conquest of the alun-alun area (Surjomihardjo 2000:21). With the encroachment of these new symbols of power around the alun-alun, the power of Javanese traditional leaders began to wane, or even in some instances to disappear completely.

During the colonial period, the weakening of the authority of traditional power-holders inevitably affected the people's interpretation of the alun-alun. It was no longer regarded with respect as an official space belonging to the 
government, but was transposed into a public space, which was accessible to anyone, high or low. Relegated to the secular sphere, the alun-alun also functioned as an urban park whose subsequent development was inextricably linked to the growth of the town as a whole. In this process, the change in the meaning accorded to the alun-alun, from a place where official activities were held to a park or an open public space, transformed it into an urban concept, which has continued to develop in more pragmatic modern times.

One of the cities in Java where people's interpretation of the alun-alun was affected by the changing balance of power is Malang. In Malang the changing meaning of the alun-alun under the impact of the rise and demise of the authorities did not end with the formation of Dutch colonial power, but continued into the Japanese period, the Indonesian Revolution and Independence. Malang occupies a special place in this respect, the more so because, as we shall see in detail shortly, it had two alun-alun.

The key question this chapter will now focus on is: What changes have occurred in Indonesia during 1930-1960 which have influenced the interpretation of the alun-alun of Malang by the inhabitants of the town and, conversely, to what extent has reference to the symbolic power of the alun-alun exerted an effect on the perceptions and interpretations of it by the townspeople of Malang? Specifically, it attempts to answer two subsidiary questions: How have the people of Malang interpreted the meaning of the alun-alun over time? And, on the basis of their perception and interpretation of the alun-alun, what (changing) activities have been performed on it?

\section{Malang: A City with Two alun-alun}

The main alun-alun of this town, called Aloon-Aloon, was established in 1882 (Kota Malang 1954:13). The shape of the Aloon-Aloon is unusual and diverges from those in traditional Javanese cities (Figure 11.1). At a first glance it does look as if it fulfils the typology of the typical Javanese alun-alun but a closer look at the location of its principal buildings reveals that it is an aberration and did not accord with the basic principles of the lay-out of a traditional town in Java, which always places the alun-alun in the 'forecourt' of the palace (kraton) or the house of the Regent.

The Aloon-Aloon was laid out under colonial rule and the way it was planned reflected the requirements of the Dutch government (Figure 11.2). The fact that it complied with Dutch priorities is betrayed by the buildings, which originally occupied the spaces around the Aloon-Aloon. The house of the AssistentResident was located on the southern side, facing the Aloon-Aloon. The mosque is 


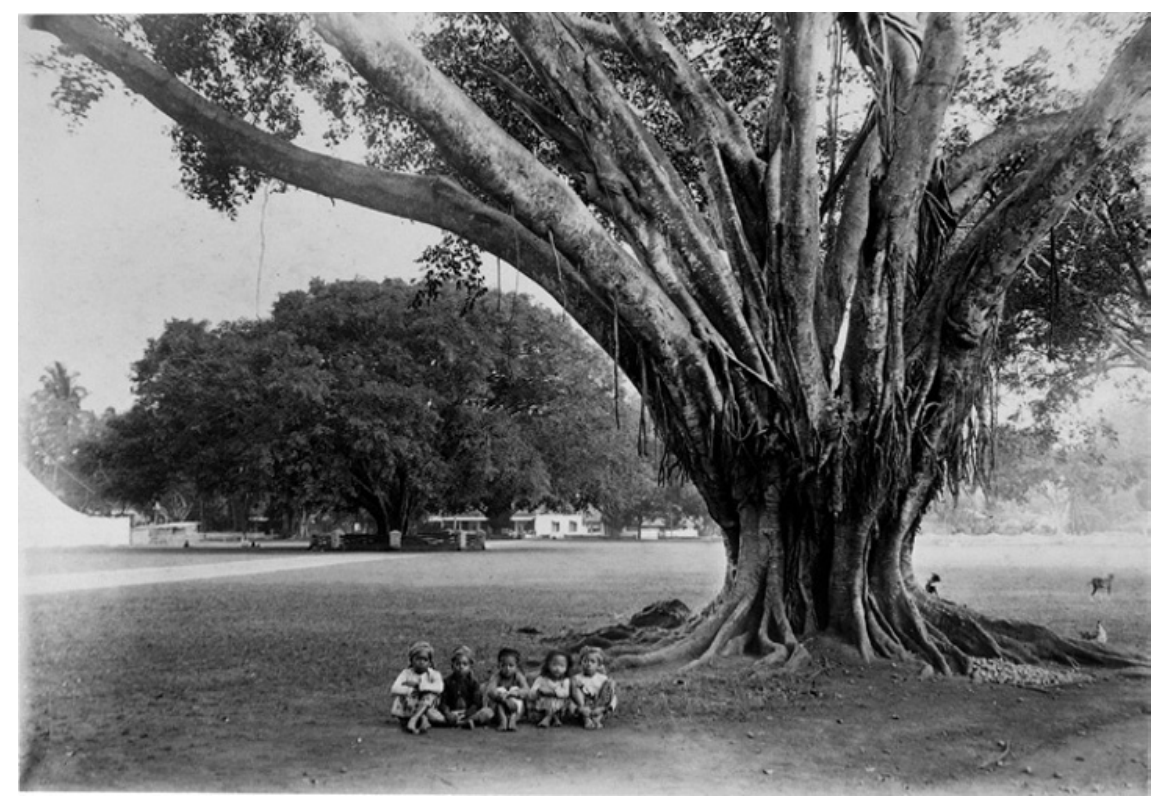

FIGURE 11.1 Aloon-Aloon, Malang, 1900

SOURCE: KITLV COLLECTION 16,473. COURTESY OF KITLV/ROYAL NETHERLANDS INSTITUTE OF SOUTHEAST ASIAN AND CARIBBEAN STUDIES, LEIDEN

to the west, as is the house of the caretaker of the mosque (kauman). On this same side stands the Protestant church. On the eastern side, there was a jail. At the north-west corner near the church stood the Sociëteit Concordia, the club which once formed the social centre of colonial society. The Regent's residence was situated somewhat removed, to the east. Significantly, it was not oriented towards the Aloon-Aloon, but faced south towards the main street, Regent Straat (Kotapradja Malang 1964:12). The layout of the Aloon-Aloon, therefore, explicitly reveals that from its inception it was intended to be an official space, but more broadly, to be a means of imposing a colonial image on Malang. As the exemplary traditional centre of the town, the Aloon-Aloon was used as a primary venue to shape that image of colonial administrative authority.

The Dutch did not see exercising power as a goal in itself, and from their overriding economic point of view, the arrangement of the colonial town had to be focused on the economic requirements of the colonial government. The strong link between colonial political power and the control of crucial sectors of the economy was clearly signified in the establishment of the Javasche Bank and Escompto Bank in 1915. Both banks were built on the Aloon-Aloon, the centre of administrative control, on the northern side to be exact (Handinoto and 


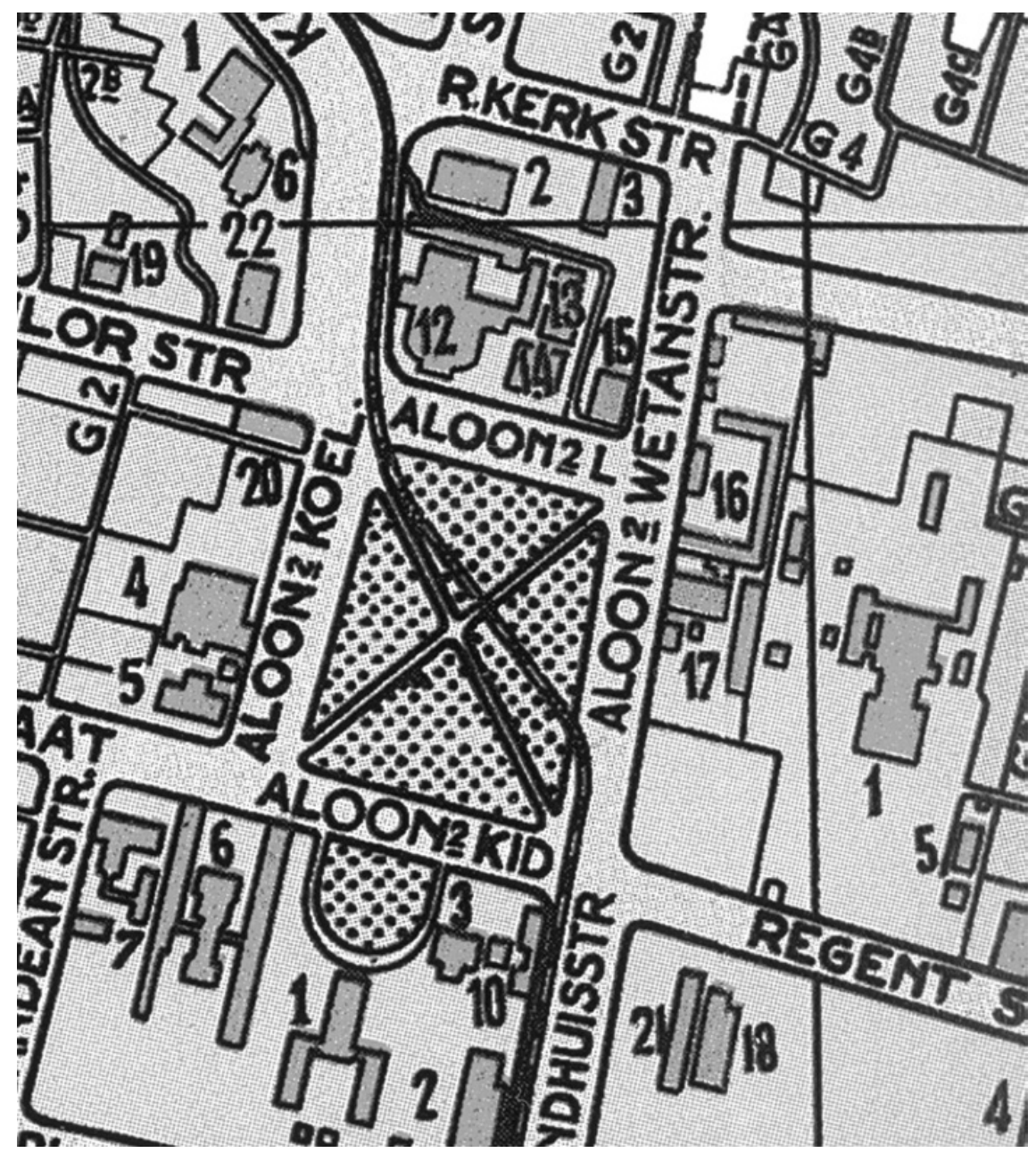

FIGURE 11.2 Aloon-Aloon in Malang during the Dutch period

Key to numbers, clockwise, starting in northwest corner: 12 Sociëteit Concordia; 14 Escompto Bank; 15 Javasche Bank; 16 jail?; 17 Regent's office; 1 Regent's residence; 18 Bioscoop Grand; 21: Bioscoop Globe; 3 Resident's office; 1 Resident's residence; 6 Hotel Palace; 5 European girls' school; 4 mosque; 20 Protestant church.

SOURCE: OFFICIEELE PLATTEGROND DER GEMEENTE MALANG 1936-1937 (PUBLISHED BY G. KOLFF, MALANG). COURTESY OF MS L.B.M. VAN LIEMPT

Soehargo 1996:52). Besides its function as a representation of the political and economic power of the colonial government, the alun-alun, finally, also became the centre of the town in another sense: it formed the nodal point in the network of urban streets. Thus, in the course of the nineteenth century, the 
alun-alun became the centre of what a number of writers have defined as the 'Indische' town (Soekiman 1996; Nas 1986). As the centre of government, it assumed the role as symbolising the authority of the colonial government.

After 1900, in Malang as in other cities in Netherlands Indies, the migration of people from the Netherlands increased significantly and this new generation of Europeans wanted to give the town a more Western air. They wanted to move the town centre away from the alun-alun. This desire was reinforced after the town of Malang was granted municipality (gemeente) status in 1914. Eventually, in 1922, the Malang municipal council created a new square and moved its offices to this area. This square was named JP Coen Plein, after the founder of the voc Empire. Nowadays it is known as the Alun-Alun Bunder; the word 'bunder' (round) refers to the circular shape of the square. ${ }^{1}$ The relocation of the municipal offices there signified that henceforward Malang possessed two alun-alun. Both alun-alun were then open spaces but a fountain erected in the middle of the Alun-Alun Bunder was intended to give the impression that this area now did duty as an urban park.

The plan to move the centre of government and urban life away from the old Aloon-Aloon reflected the desire to define a European-dominated centre as the sole locus of authority. The Dutch administration considered the AloonAloon unsuitable as the centre of a modern city since it was already occupied by the indigenous people from late afternoon to well into the night. Thomas Karsten, the prominent architect and town planner, was assigned this task. Planning for the design of a new alun-alun commenced in 1917, soon after Malang was granted municipal status (Handinoto and Soehardjo 1996:65).

The layout of the Alun-Alun Bunder was intended to encompass the beautiful environs of the town. This beauty was derived from the mountainous scenery with which Malang was surrounded, the main highlights being Mount Kawi to the west, Mount Semeru to the east, Mount Arjuna to the north, and the valley of the Brantas River, which flowed through the town. In the 1920 s the beauty of this mountain scenery could no longer be appreciated from the Aloon-Aloon as many buildings blocked the vistas. Thomas Karsten envisaged a new angle of vision and the Alun-Alun Bunder was the result. The Alun-Alun Bunder helped to promote the reputation of Malang as a garden city (Hall 1993:87-135).

When designing the Alun-Alun Bunder as the new municipal centre, Karsten took account of Javanese traditions. His design for the Alun-Alun

1 In the remainder of this chapter I refer to it as the Alun-Alun Bunder and not as JP Coen Plein, also for the colonial time, to emphasize that I treat the two places as belonging to one category of alun-alun. 
Bunder, providing an open area in front of the government buildings, was based on the design principles of the Kraton of Yogyakarta or Surakarta. The design of the Alun-Alun Bunder complex was based on a similar north-south axis which linked the Southern Ocean, the town hall, the Alun-Alun Bunder itself with a water fountain in the centre, and Idenburg Straat, in an imaginary line straight to Mount Arjuna in the north. This layout of the Alun-Alun Bunder also paralleled the layout of municipal buildings in Semarang, which had also been inspired by the Kraton of Yogyakarta. Even the internal division of the town hall of Malang into rooms replicated the kraton. ${ }^{2}$ Where the kraton had its siti hinggil, the audience hall in which the ruler welcomed his high-ranking court servants, the town hall had a room in which the mayor (burgemeester) met the councillors. Just as the Sultan of Yogyakarta would be seated so that he looked north, in the direction of Mount Merapi, the position of the mayor was such that he looked north in the direction of Mount Arjuna when he met the council.

Although unquestionably based on traditional Javanese design and philosophy, the Alun-Alun Bunder was in other respects a thoroughly European complex. Named after the fourth Governor General of the voc, Jan-Pieterszoon Coen, it celebrated Dutch might. Unlike the Aloon-Aloon, local, indigenous people did not gather there. Unquestionably the reference to Jan-Pieterszoon Coen and the shape of the new square were significant, but the actual physical location of the Alun-Alun Bunder was also brimming with significance by repositioning Malang as a town within the conceptual design of the traditional Javanese town. The explanation for this apparent 'traditional step' can be found in the fact that the Alun-Alun Bunder was designed by Thomas Karsten, an architect with strong democratic-socialist tendencies. Karsten was opposed to the direction adopted by contemporary colonial policies and was interested in the potential and resources offered by the form of traditional Javanese building (Bogaers and de Ruijter 1986:71-88; Coté 2014; Van Roosmalen, this volume). Through the medium of a colonial town design, Karsten expressed his criticism of contemporary colonialism and whether or not his idea was wholly realized, the presence of the Alun-Alun Bunder and its municipal buildings was an endeavour to return to the original idea of the Javanese town which had been destroyed by nineteenth century colonial design.

As a result, the two alun-alun in Malang were both spaces imbued with strong symbolic meanings. So far, the analysis has been confined to the design of these spaces and the discussion of urban symbolism has so far

2 The town hall of Malang was designed by H.F. Horn (Pauline van Roosmalen personal communication). 
been somewhat one-sided, as only the symbolic meanings attributed by the powerful have featured. In what follows I attempt to redress this imbalance by discussing the way various groups in society have attributed meanings to the two alun-alun. When all is said and done, all urban residents have their own interpretation of the urban symbols. They can ascribe meanings quite different from that intended by the people who originally created these spaces. Therefore, the purpose of this study is to go a step beyond describing the alunalun as a consciously created symbol and examine how those symbols have been shaped, altered, and maintained and understood.

\section{The Struggle for the alun-alun of Malang in Dutch Times}

Those who conceived the plan for the development of the Aloon-Aloon might never have thought that the alun-alun which they constructed as the symbol of colonial superiority would in the end be conquered so quickly by the people they colonized. The conquest is clearly represented in a black and white photograph of the Aloon-Aloon originally taken in the late nineteenth century (Figure 11.3). Vendors of food and drink (verkoopers van eet en drinkwaren) have invaded the area. They are sitting under the banyan trees, which were then between ten and twenty years old. The shade of the leafy trees planted in a row at the edge of the alun-alun pervades the square with a sense of coolness. It is in the shade of these banyan trees that the 'conquest' of the alun-alun by the vendors has been affected. Behind their angkringan (small cupboards situated on poles), they can be seen diligently serving their customers, who are seated in front of the angkringan on plaited mats. By comparison to these dozens of indigenous food and drink vendors and their customers, the colonial power seems very small. Even, the Assistent-Resident's office seems to fade into the distance.

The presence of the indigenous people who gathered around the alun-alun every evening created a binary opposition to the situation outside the alunalun, which was still completely dominated by European colonial power. Every evening until deep in the night the fight against colonialism was staged on the alun-alun, even though it did not take the form of physical warfare. In the period of 'rust en orde' (law and order), more open armed resistance would have been futile because the state would have suppressed it by the force of its superior modern armaments.

As discussed above, the development of the original Aloon-Aloon was intended to present an image of colonial power by manipulating the symbolic meaning traditionally applied to this open space. The spatial arrangement of 


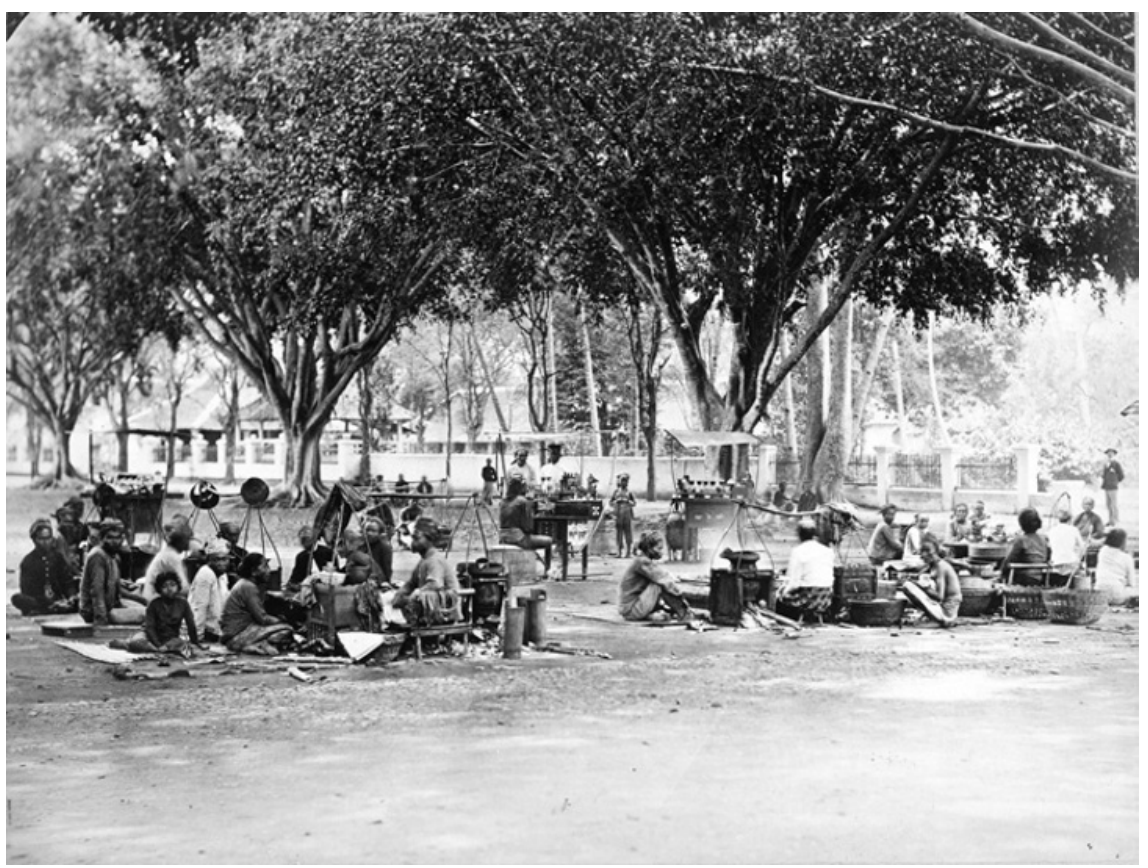

FIGURE 11.3 Vendors on the Aloon-Aloon, Malang, 1895

SOURCE: KITLV COLLECTION 12,030. COURTESY OF KITLV/ROYAL NETHERLANDS INSTITUTE OF SOUTHEAST ASIAN AND CARIBBEAN STUDIES, LEIDEN

the colonial town was consciously adapted to be the centre of the colonial administration as well as representing, at the local level, its unchallenged economic power.

This may have been so in theory, but in the case of Malang the attempt to build colonial prestige on the vestiges of the original Javanese town by appropriating the alun-alun failed. Although in physical terms the Aloon-Aloon was reminiscent of the Javanese spatial arrangement, it failed to encapsulate the actual idea and significance of the Javanese concept of alun-alun. From the outset, by locating it to the west of the seat of traditional Javanese authority, (that is, in an inappropriate position), the Aloon-Aloon was perceived by indigenous residents to be the square of modern power. Colonial power in Malang was never perceived as being represented through the medium of the open space called the Aloon-Aloon. In fact, the reverse was true: the Aloon-Aloon became a representation of colonization and was transformed by the colonized people into the vehicle of their opposition to colonialism.

The colonial image was expressed in the form of various buildings erected next to each other around the alun-alun (Figure 11.2). A variety of colonial 
activities took place inside the rooms of these buildings but significantly, not on the alun-alun itself. With the exception of the Great Mosque on the western side of the alun-alun, all the edifices surrounding it were buildings, which served the needs of the colonial state. This colonial image was reinforced in 1912 when a Protestant church was built on the western side of the alun-alun, on the Aloon-Aloon Koelon Straat, to the north of the mosque. The presence of this church exuded an impression redolent of Christian (Western) domination of the Muslim (indigenous) people whose Great Mosque of Malang had been built in 1875 , several years before the alun-alun was developed. The tall church spire seemed - as was, no doubt, intended - to overwhelm the mosque to its south, which now appeared diminutive in comparison. The domination by construction continued in 1915 and 1916 when two Western edifices were erected almost simultaneously on the northern and southern sides of the alunalun. One, the Javasche Bank, was built in Aloon-Aloon Lor Straat, designed by Hulswit \& Fermont and Ed. Cuypers and opened in December 1915. The other, the Palace Hotel, opened some months later in 1916 at the southwest corner. The ground plan of these two buildings revealed a strongly symmetrical pattern that was immediately apparent in their appearance. The gate of the Palace Hotel consisted of a double tower, which strengthened the impression of the colonial desire to take charge of the centre of the alun-alun. In 1929, the Escompto Bank was established to the west of the Javasche Bank. The colonial image was reinforced even more strongly by the prominence of these two Western economic institutions.

Nevertheless, the colonial image, which these buildings exuded, paled in comparison to the even stronger image radiated by two other buildings on the alun-alun: the Sociëteit Concordia and the Bioscoop Rex. These two buildings, a social club and a cinema, were essential to the décor of a Western life-style. The many European social activities, which were held at the Sociëteit, including dancing, pool games, playing cards, and many other pastimes, sharpened the awareness of the indigenous people of Malang that they were dominated by an alien group. The social distance was reinforced by the fact that they were warned not to enter the area. The Bioscoop Rex embodied this distance with its 'living screen', which was at that time the most modern form of entertainment devised by Western technology. Those two entertainment venues were obviously far beyond the reach of indigenous people, especially those from lower social classes. For the poor it was impossible even to imagine being able to set foot in these places.

However, if the indigenous people could not take part in the colonial social activities inside the buildings surrounding the alun-alun, they could at least defy the Western life-style. They might be unable to enjoy the delicious food 
served in the renowned Oen Restaurant opposite the Sociëteit Concordia, but food and drink vendors from their own ranks appeared like clockwork on the southern section of the alun-alun, selling their merchandise from dusk till late at night. While European people relaxed in the Sociëteit Concordia, the indigenous people could also enjoy themselves, not in the sociëteit, but in front of it on the alun-alun. They could drink coffee and eat peyek or gulai sold by people from Ponorogo. As European people enjoyed the art of dancing to the music of the waltz or were entertained by the comedies on the 'living screen', indigenous people could delight in the art of dance in a ludruk (Javanese folk theatre) performance presented at the north-eastern corner of the alun-alun behind gedek (panels of plaited bamboo).

Cultural resistance grew even stronger when religious ideology entered the arena. To those indigenous people of Malang who were obedient to Islamic teachings, such European areas as the sociëteit or bioscoop were prohibited territory. In their eyes, the goings-on of the European people were sinful and the area was considered haram (forbidden), a place to be avoided. People in those areas were indulging in pleasures banned by Islamic doctrine, such as being drunk, gambling, dancing, and so on. So, it was on the alun-alun that the indigenous people could have fun and enjoy the entertainments permissible under the tenets of Islamic teachings.

As indigenous people encroached on and began to conquer the alun-alun, the government itself began to neglect and then intentionally undermine the meaning of the place as a symbol of colonial power it had originally ascribed. The authorities began to regard the square as simply a common open space devoid of any overly potent associations. This change in view was revealed to the full light of day when a tramline, which connected Malang to Dampit, was developed. From Blimbing Station the tramline ran via Lowokwaroe, Tjelaket, and Kajoetangan Straat, the main streets of European economic centre in Malang, towards the alun-alun. Approaching the alun-alun area, instead of being routed around it, the tramline continued straight through it, dividing it diagonally from the north-west to the south-east corner (Figure 11.2). Furthermore, a tram stop was constructed exactly in the middle of the alunalun under the banyan tree, to allow tram passengers to get on and off (Van Schaik 1996). The existence of a profane tram stop under the banyan tree even undercut the symbolic image of the alun-alun as an official space owned by the government. This spot was thronged with people every time a tram stopped with passengers wanting to get on or to alight. The banyan tree, which was once considered sacred in the context of Javanese culture, was deprived of its aura as the crowd of modern-day tram passengers used it casually as a tram shelter. 
Other evidence that the alun-alun no longer really held any significance for Europeans or for the municipal government in Malang was its exclusion from the Malang urban development plan. Following the decision to classify Malang as a municipality (gemeente and later stadsgemeente) in 1914, an urban development plan (bouwplan) was drawn up. The plan, which divided Malang into various development zones, was implemented progressively in eight stages, from Bouwplan I to Bouwplan VIII. Not one of the eight development zones related to the Aloon-Aloon. Generally these section plans focused on the needs of the European people. For example, Bouwplan I, which was commenced in 1917, provided a housing area for European people in the Oranjebuurt, the neighbourhood around Tjelaket. Bouwplan II, approved in 1920, concentrated on the area near the Alun-Alun Bunder, with the objective of developing it into the new centre of municipal government. This area was then generally known as the Gouverneur-Generaalbuurt (Governor General Neighbourhood), because all the streets in this area were named after Governors General of the Netherlands Indies. Bouwplan III pertained to the European cemetery. Bouwplan IV involved the construction of a housing complex for middle class people and was located west of Tjelaket and Lowokwaroe. The goals of Bouwplan V to Bouwplan VIII were similar and were overwhelmingly concentrated on providing housing for Europeans. The Aloon-Aloon, which had been effectively usurped by indigenous people, was not included in any of the bouwplannen (Jaarverslag 1940 1941).

After the construction of the Alun-Alun Bunder and the municipal buildings were completed, neither the colonial nor the municipal government planned any public festivals on the Aloon-Aloon. In the years 1937-1939, for example, the municipality organized several huge festivals to celebrate events related to the Dutch royal House of Orange: the marriage of Princess Juliana and Prince Bernhard, the birth of their first two children, and the fortieth anniversary of the reign of Queen Wilhelmina. The festivals centred on the AlunAlun Bunder, not on the Aloon-Aloon (Van Schaik 1996:42).

Nevertheless, the Aloon-Aloon was not totally ignored by Europeans. In 1938 it was reported that people from the nearby Roman Catholic Church (located to the north of the Sociëteit in Kayoetangan Straat) had attempted to hold open-air church services there on Sunday evenings. One elderly resident recalled that the Roman Catholic priests would come and set up tables loaded with books and pamphlets and chairs under the banyan tree on the eastern side of the alun-alun (interview with Azis Salim). After everything was ready, a Catholic priest dressed in his white alb would begin to preach the 'good news' of Christ and read from the Bible. Initially his presence attracted an audience of local people to whom assistants distributed pamphlets expounding on 
Christianity. Young children in particular were attracted by the arrival of the priests on the alun-alun. In their eyes, they must have appeared like sellers of medicinal herbs; but the sound of a loud voice in an open public place will always attract children's attention. In any event, those children were probably more attracted by the pamphlets distributed by the preacher and his assistants. In 1938 paper was still a great rarity for children in Malang. It was not long, however, before people realized the purpose of this activity was to convert them and they stopped coming.

The activity of Roman Catholic priests was an attempt to re-empower the alun-alun. The priests expressly positioned themselves in the eastern part of alun-alun, opposite the Great Mosque, which was located on the western perimeter. Both the location and the mission of the Catholic priests was an attempt to create an opposition within the confines of the alun-alun. Muslims regard the mosque as a place to pray and it is central to the religion and the community of the local people. When war broke out, for instance, the mosque was used as a place to discuss the strategies with which to attack enemies. The priests who attempted to preach Christianity on the alun-alun were seen as infidels by the local Muslims. In fact, this attempt to propagate Christianity was soon halted because it attracted only young children. In any event, according to Azis Salim, my main informant on the matter, evangelization vanished with the arrival of Japanese to Malang.

Even sporting activities, so much part of the European life-style and which required a large open space, were not held on the Aloon-Aloon. The Fifth Development Plan for Malang included a huge sports park consisting of a stadium, a hockey field, two soccer fields, nine tennis courts, a clubhouse, and a swimming pool (Stadsgemeente Malang 1939). At the time it was constructed, the stadium was probably the best and biggest in Indonesia. This sports area was a propitious focal point as European people could enjoy the beautiful panorama of Mount Kawi to the west as they participated in or watched the various sporting activities. Mount Kawi was named 'De Liggende Vrouw' (The Sleeping Woman) in Dutch, because when it is viewed from far away, it resembles a recumbent woman sleeping.

\section{The Arrival of the 'Older Sibling'}

On 8 March 1942, the Japanese Army entered Malang. The arrival of thousands of Japanese soldiers was received with mixed feelings by the citizens. The indigenous people had high expectations of them as 'older siblings' who would relieve them of the colonization by the Dutch. At the time, Indonesians were 
obsessed with Joyoboyo's prophecy, which predicted that kate (tiny) people would come from the East to release them from the suffering caused by colonialism.

In contrast to the indigenous people, Chinese people, especially women, were terrified by the Japanese arrival. They had learnt that previously the Japanese had attacked their mother country, sought out attractive women to slake their lust, and were very cruel. By the time the Japanese soldiers arrived in Malang, many attractive Chinese women had exchanged their fine clothes for pating srediwil (ragged clothes), scratched or disfigured their faces with make-up, and tousled their hair in an attempt to camouflage their features. By taking these actions, they hoped to elude the attentions of Japanese soldiers and avoid being raped by them (Berdoeri 2004:185).

Remarkably, upon arrival in Malang, the Japanese soldiers first set down, not in the Alun-Alun Bunder, which was clearly the seat of the government and the mayor (burgemeester) but in the Aloon-Aloon. The situation there when the Japanese soldiers arrived was described expressively by Tjamboek Berdoeri in his book Indonesia dalem api dan bara.

When I arrived on the alun-alun [the Aloon-Aloon], the large field was thronged with more people than I had ever seen before. Japanese soldiers who were all busy preparing things to fill their stomach occupied the Resident's front garden. Some were cooking porridge; others were opening their backpacks to take out chopsticks and bowls. In short, the scene they presented was as if Malang was being visited again by a large hobbyhorse troupe, whose members were first finishing off their own affairs before sticking poles into the ground to set up tents. [...] Some Japanese were taking off their clothes and allowed their navels to peep from above the waistband of their trousers at the audience who had come in swarms to behold those new guests. Some were wearing dirty trousers, which plainly showed that they had been everywhere, pulling in the belts again and again to keep them from sliding down. ${ }^{3}$

3 'Koetika saja sampe di aloon-aloon, ternjata jang itu lapangan loewas penoeh sesak sama riboean orang, seperti jang belon perna saja liat. Pekarangan depan dari roemah Resident di tempatin oleh serdadoe-serdadoe Djepang jang itoe waktoe lagi repot boeat masing-masing sediaken barang boeat tangsel peroetnja. Ada jang masak boeboer, ada jang boeka bangkelannja oentoek keloearkan soempit serta mangkoknja. Pendek kata, marika itoe waktoe kasi pemandengan begitoe roepa seolah-olah Malang lagi ketamoean komedie-koeda jang besar dan jang personeelnja lagi beresin doeloe kaperloeannja sabelonnja marika moelai dengen tantjepken tiang-tiang dalem tanah boeat pasang tendanja. [...] Ada jang boeka 
This short description vividly sketches the scene on the Aloon-Aloon thronged with people who had come to witness the initial arrival of the Japanese. Normally, it would have only been crowded in the evenings, but now, during the day, it was suddenly occupied as if by an audience attracted by a group of hobbyhorse players who were just getting down off their vehicles. The Japanese decision to regroup on the Aloon-Aloon raises the question of why they did not go straight to the Alun-Alun Bunder where the town hall was situated. Its buildings would have been more comfortable as a place for the soldiers to rest after their battles and long journey. There were more rooms, including many bathrooms, and better furnishings than were available in the house of the Resident located there. They could also have gone to Rampal, an area in Malang occupied by the colonial army during the Dutch colonial period. But instead the Japanese soldiers chose the Aloon-Aloon as the first place to visit.

The Japanese commanders probably understood that the Aloon-Aloon belonged to the people; that the people of Malang had a stronger sense of belonging to this alun-alun than to the colonial Alun-Alun Bunder, which had been an elite place from which Malang urban life had been controlled in Dutch times. This psychological connection was manipulated by the Japanese, who desired to be regarded as the 'older sibling' and so decided that the 'younger siblings' should be visited first. From the Japanese point of view, the Alun-Alun Bunder and its environs needed first to be cleansed of the presence of the Dutch enemy who had been reigning over their younger sibling. This would be done after the younger sibling had been greeted.

Another interpretation of the Japanese decision to go to the Aloon-Aloon might be that the Japanese military wished to well and truly sever all links with the evidence of Western colonialism. Therefore all such Western symbols as the Alun-Alun Bunder were to be avoided. In general, the Japanese policy was to suppress evidence of Dutch colonialism by such measures as banning the use of the Dutch language as a spoken and written vehicle of communication throughout Indonesia. All schools that had previously used Dutch as the language of instruction were required to switch to Indonesian.

The Japanese, then, also planned to make use of the symbolism attached to the alun-alun, in their case in an attempt to embrace Malang and make the idea of a Greater East Asia a reality. The next action the Japanese army took

badjoe dan biarin sadja poesernja maen-mata dari atas kepala-tjelananja sama publiek jang dateng bergroemoetan boeat liat itoe tetamoe-tetamoe baroe. Ada jang dengen tjelana jang mesoem kaliatannja djalan kian-kemari sembari saben-saben tarik saboeknja soepaia djangan terlalu mobrat-mobrot.' 
was to replace the Dutch mayor of Malang, J.H. Boerstra, installing in his stead Raden A.A. Sam, previously the Regent of Malang. During the Japanese occupation he held three positions simultaneously: Regent, Resident, and mayor. This was a clever strategy on the part of the Japanese to empower the indigenous people, since it would have been quite possible for them to replace the Dutch mayor with a Japanese candidate, a choice which they eschewed.

In June 1942, a very symbolic event took place when an official ceremony was held to welcome the arrival of an important detachment of the Japanese Army to Malang. An official photograph of this occasion taken from the veranda of the home of the Resident shows a number of prominent Japanese soldiers, including the local commander Colonel Kato, either seated or standing around the Resident, Raden A.A. Sam. Other indigenous officials are seated slightly to the rear or to the side (Figure 11.4). Not visible in the photo but a fact known from reports of the occasion, were the thousands of Japanese soldiers lined up on the central part of the alun-alun in front of the high-ranking officials (Van Schaik 1996:52). The event was intended to demonstrate the warm relationship between the inhabitants of Malang and the Japanese army.

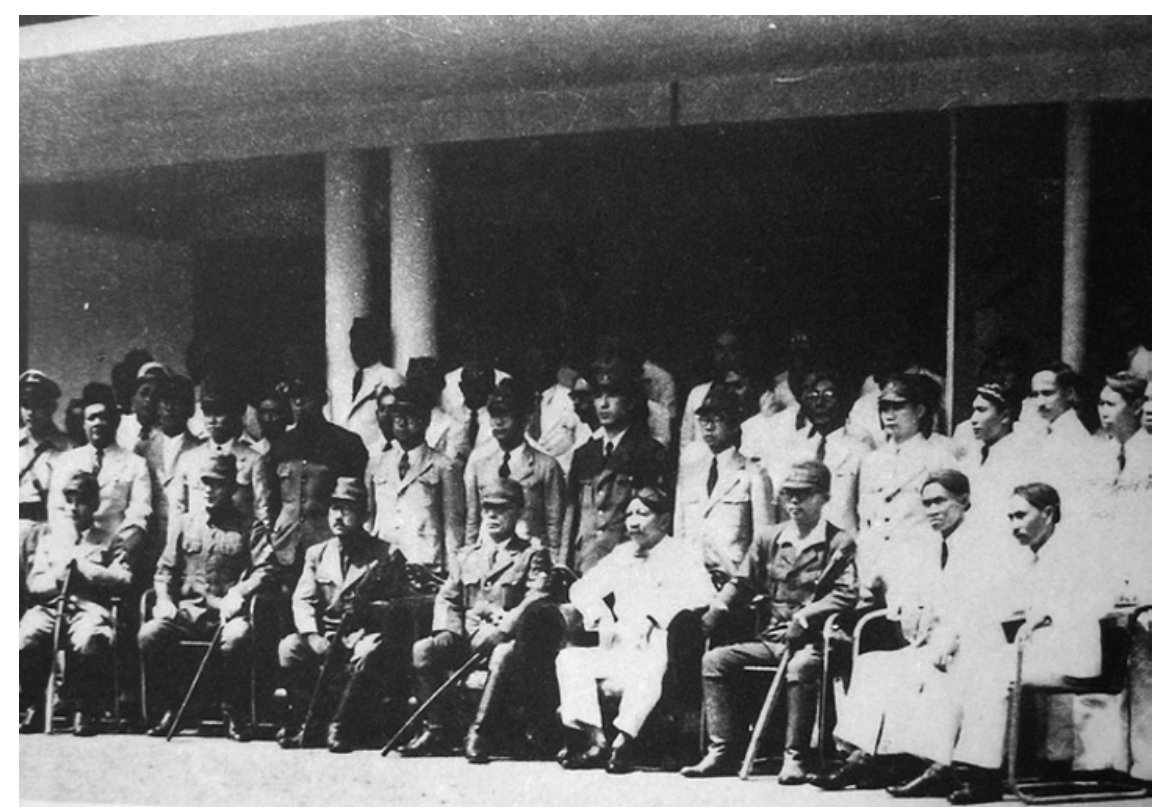

FIGURE 11.4 Resident Raden A.A. Sam and Japanese officials, 1942 SOURCE: VAN SCHAIK (1996:52; COURTESY OF MALANG STUDIO, MALANG) 
Initially, the Aloon-Aloon could be said to have been used to demonstrate the love affair between the indigenous residents and the Japanese soldiers. Later, this romance faded as the people of Malang began to suffer because the Japanese soldiers treated them even more brutally than the Dutch had done. One interviewee, mbok Satiah, a rice seller on the corner of Kayoetangan Street, remembered:

I was still about eight years old in the Japanese period. The Japanese soldiers were very brutal. Once, they arrested a man without any explicit reason. The man was beaten and dragged to the alun-alun. Some Japanese soldiers dug a hole a metre deep in the southwest corner. He was forced to get into it and was buried up to his neck. It was exactly the same as the stoning to death law in stories about the Prophet (Interview with mbok Satiah, 22 February 2005).

By what seems a strange twist of fate, during the Japanese occupation, the Aloon-Aloon was used as an arena in which the brutality perpetrated by Japanese soldiers against their younger sibling was publicly exposed, after having first being used as a symbol to demonstrate common interests between older and younger siblings. This brutality was never exercised on the AlunAlun Bunder, so that it would seem that that public space was allowed to remain a centre of a sacred and untouched authority. It is not easy to comprehend the meaning of the brutality displayed by the Japanese soldiers in the example above, but unquestionably the Aloon-Aloon was transformed into an unruly space, akin to a deserted garden or wilderness in which the law of the jungle prevailed. During the Japanese period in Malang the Aloon-Aloon degenerated into a place robbed of its worth, degraded by the actions of Japanese soldiers but also in the perception of the people.

Mbok Satiah was keenly aware of this phenomenon. During the Japanese period, she also recalled, there was a well-known soto (soup) seller who traditionally hawked what people believed to be beef soto on the southern part of the alun-alun. One day, as he was busy serving many buyers, his son ran up to him and shouted: "Daddy, they are running away!" "What are running away?" his father asked. The boy's answer shocked the customers and made them nauseous: "The cats which are going to be slaughtered for soto are escaping. The cage door was unlocked." The soto seller was immediately reported and the Japanese soldiers came and dragged him away. His life ended then and there (Interview with mbok Satiah, 22 February 2005).

The alun-alun, therefore, became debased, a location where different groups exploited one another and where the exploiters were not always 
necessarily foreigners. The acts of brutality showed no respect for religious feelings. When local people were forced to perform seikere on the alun-alun, the act of taking a bow towards the sunrise to honour ameterasu omikami, this constituted a brutal assault on their religious belief. Even though the alun-alun was surrounded by houses of worship, most prominently a mosque and a church, those religious symbols could not offer 'succour' to their members who suffered at the hands of Japanese soldiers. One example was the experience, which befell a hajji on the southeast corner of the Aloon-Aloon. The incident took place soon after the arrival of the Japanese army in Malang. One day a man dressed as a hajji rode his bicycle from the north side of Jalan Aloon-aloon Wetan pedalling in a southerly direction. His bicycle was decorated with two flags: the Japanese and the Indonesian. Coincidently, a Japanese soldier happened to be standing with a rifle on his shoulder on the corner of the alun-alun. Catching sight of a hajji riding the bike with the two flags, the soldier stopped him. Without uttering a word, the soldier pulled off and tore up the red and white (Indonesian) flag. The Japanese soldier, possibly ignorant about the Indonesian flag, saw only that it had the same colours as the Rising Sun, but its design was incorrect. The hajji, seeing that one of the flags had been torn to tatters by the soldier, thought that he was not supposed to decorate his bicycle with any flags so he also he pulled off the Japanese flag as he was in a hurry to save himself from a beating by the soldier. However, the Japanese soldier, now believing that his flag was being insulted by the hajji, hit him with the butt of his gun. Feeling proud of what he had done, the soldier walked away leaving the hajji rubbing his head to ponder his experience of true samurai blood (Berdoeri 2004:195-6).

During this period, the alun-alun was also deemed a strategic place on which Japanese collaborators and 'betrayers' could express their thoughts. This became apparent during the latter part of the Japanese occupation when it clearly emerged who the traitors and those people who longed for the past were. Novelist Tjamboek Berdoeri describes one occasion when a man he considered to be a hankan (traitor to his country) or collaborator, delivered a speech on the alun-alun. It seemed that the man was a Eurasian even though he looked Indonesian. He loudly criticized everything, which could be linked to full-blood Dutch people who had suppressed Eurasian people and had refused to care for them. Consequently, he was grateful to the Japanese army, which had come to save them (Berdoeri 2004:226). This act of defiance was deliberately staged on the alun-alun because it was an open public space, commonly visited by local people and symbolically the place 'nearest' the Japanese soldiers. 


\section{Independence}

Independence ushered in a euphoric period for Indonesia. Independence was a magic word, which led people to believe they could do anything they wished: they were free. An indigenous person could feel free to break a Chinese shop window for instance. If he did so, the very frightened owner would hand over everything that was demanded in order to save his life. Independence also meant freely taking over anything colonial and destroying colonial symbols. Independence was freedom. In this period the Aloon-Aloon Malang and its environs was transmuted into an area where the euphoria of this freedom could be expressed.

In August 1945, shortly after the Proclamation of Independence, signs of this freedom of expression began to appear in Malang. Slogans were written on the walls of colonial buildings on the Aloon-Aloon. There was a big handwritten sign on the wall of the Nationale Handelsbank, next to the Palace Hotel, which read "Freedom is the Glory of any Nation". There was even a bigger slogan below it saying "Indonesia for Indonesians!" (Kota Malang 1954:23).

A more formal attempt to take control of the alun-alun space was in the form of changing the names of the buildings in the area. The name of Palace Hotel was changed first to Hotel Merdeka (Freedom Hotel) and later to Hotel Pelangi (Rainbow Hotel). Bioscoop Rex was changed to Bioskop Ria (Cheerful Cinema). Sociëteit Concordia was changed into Gedoeng Rakjat (House of the People). These name changes were intended to show that, having gained independence, all residents of Malang had in principle now the right to enjoy the entertainment offered by these facilities.

The 'liberation' of the Gedoeng Rakjat and its transformation into a public meeting place assumed even more symbolic significance when the newly established government of Indonesia in Jakarta chose the building as the venue in which to conduct the first meeting of the Komite Nasional Indonesia Poesat (KNIP, Central National Committee of Indonesia). The KNIP was founded as an organization to represent the Indonesian people, to fill the gap before a representative parliament could be directly elected. Between 25 February and 5 March 1947, the Gedoeng Rakjat entered history as the first place in which the people's representatives of the KNIP gathered. No fewer than 1500 people from throughout Indonesia visited the building to participate in, or just to witness first hand, the enactment of Independence.

The alun-alun and the surrounding buildings were not subjected to any physical changes. Nevertheless, the perspective of them among the Indonesian people and the way they treated these buildings had totally changed. Whereas previously in the colonial period the alun-alun and buildings had been 
separated from one to another - the alun-alun for the common people, the buildings (except the mosque) for the colonial elite - with the coming of Independence, the alun-alun and the surrounding buildings were closely linked together. The opposition between the people's space and the space of the colonial power had been obliterated. Nevertheless, it proved no easy matter to maintain this new spatial unity.

On 22 July 1947, as part of the large-scale First Dutch Offensive (Agresi Pertama, or Eerste Politionele Actie), Dutch soldiers launched an attack on Malang. The response of the inhabitants of Malang was to prevent the newly gained symbolic unity between square and buildings from falling apart in this very critical situation; their reply was to set fire to all the colonial buildings to prevent the Dutch from reoccupying them. The Great Mosque of Malang was the only building around the Aloon-Aloon spared from the Republican forces' scorched-earth policy. According to a report by the contemporary local authorities, about a thousand buildings were burnt down (Kotapradja Malang 1964:19). This number seems an exaggeration but certainly all the colonial buildings around both the alun-alun were razed and the report by the Kotapradja indicates that a large number of buildings throughout the town were also destroyed as a result of this policy.

The newly returned Dutch government struggled to regain control of the town in a military and administrative sense, and in its endeavours it again did not overlook the value of symbolism. Symbolic control included an attempt to reappropriate the Aloon Aloon. On 2 October 1947, only two months after the Dutch army had seized the town, Major-General M.R. de Bruyne officially dedicated a monument to commemorate the deaths of marines and Koninklijk Nederlandsch-Indisch Leger (KNIL, Royal Netherlands Indies Army) soldiers at the hands of Republican forces. The monument was in the form of a five-sided conical pillar on which were inscribed the names of the slain Dutch soldiers and a line from the Dutch national anthem (Van Schaik 1996:80). The monument was a symbol that the Aloon-Aloon was once again ruled by the Dutch. To emphasize this message, the monument was built exactly opposite of the mosque.

The arrogant action of erecting a monument in front of the mosque, the holiest place in the town as far as the Muslims in the Indonesian population were concerned, was interpreted as a huge insult. Angry as they were, the local people could do nothing about it, as they were faced by soldiers armed with guns. Understandably, when sovereignty was returned to the Indonesian Republic, one of the first actions taken by the municipal government was to demolish the monument. This event symbolized the return of the Aloon-Aloon to its authentic owners. 


\section{The Struggle for the Alun-Alun Bunder}

In the meantime, how did the Alun-Alun Bunder fare through this tumultuous period? As described above, on its arrival the Japanese occupation force made its first appearance on the Aloon-Aloon, rather than on the Alun-Alun Bunder. Although intent on erasing all symbols linked to the Dutch colonial regime, no action was taken against the Alun-Alun Bunder by Japanese soldiers. It was only after Independence that attempts were made to 'decolonize' the AlunAlun Bunder and assert the Indonesian people's full rights to all areas in Malang. As a sign of this right, a monument to liberty was erected in the middle of the Alun-Alun Bunder where previously the fountain had stood. This monument had a dual function. It served as a remembrance monument and as a tetenger (symbolic marker) from which central point the area described by the radius was officially 'ours'. Unlike the Aloon-Aloon, the Alun-Alun Bunder had been dominated up to the very last seconds of Dutch colonialism in Malang, and a physical sign that the alun-alun was no longer under Dutch control was essential.

Malang lay within the region controlled by the Republic and to commemorate the first year of Independence, a ceremony was conducted on 17 August 1946, to lay the foundation stone of the Independence monument. A model of the monument was unveiled on the occasion (Figure 11.5) and the event was attended by Doel Arnowo, hero of the Battle of Surabaya (November 1945) and assistant to the governor of East Java at that time. Soenarko, Resident of Malang, also attended. The monument was almost completed by the time Dutch forces seized Malang in the First Dutch Offensive (Agresi Pertama), July 1947 .

In the Dutch return to Malang there was more at stake than a simple military campaign; they also found themselves embroiled in a fierce symbolic struggle to recapture the town. The Dutch were perceived as acting as the tiger in Javanese mythology, which makes an area previously staked out by the urine of the tiger's enemy sangar (neutral). In the eyes of local people, Dutchmen actually resembled fearsome, rapacious tigers while they conceived of themselves as the wild bulls ready to combat the tiger by wielding their sharp horns effectively. In this metaphor, the potency of the enemy of the tiger was represented by its ability to demolish the monument, and this proved to be the only means the Dutch tiger had at its disposal to make the monument sangar. Before demolishing it, Dutch soldiers had already used a subtler way to dominate the monument by swathing it in a huge Dutch red, white, and blue flag. The peak of the monument was topped by a European crown representing Queen Juliana, handily symbolizing the return of Dutch sovereignty without 


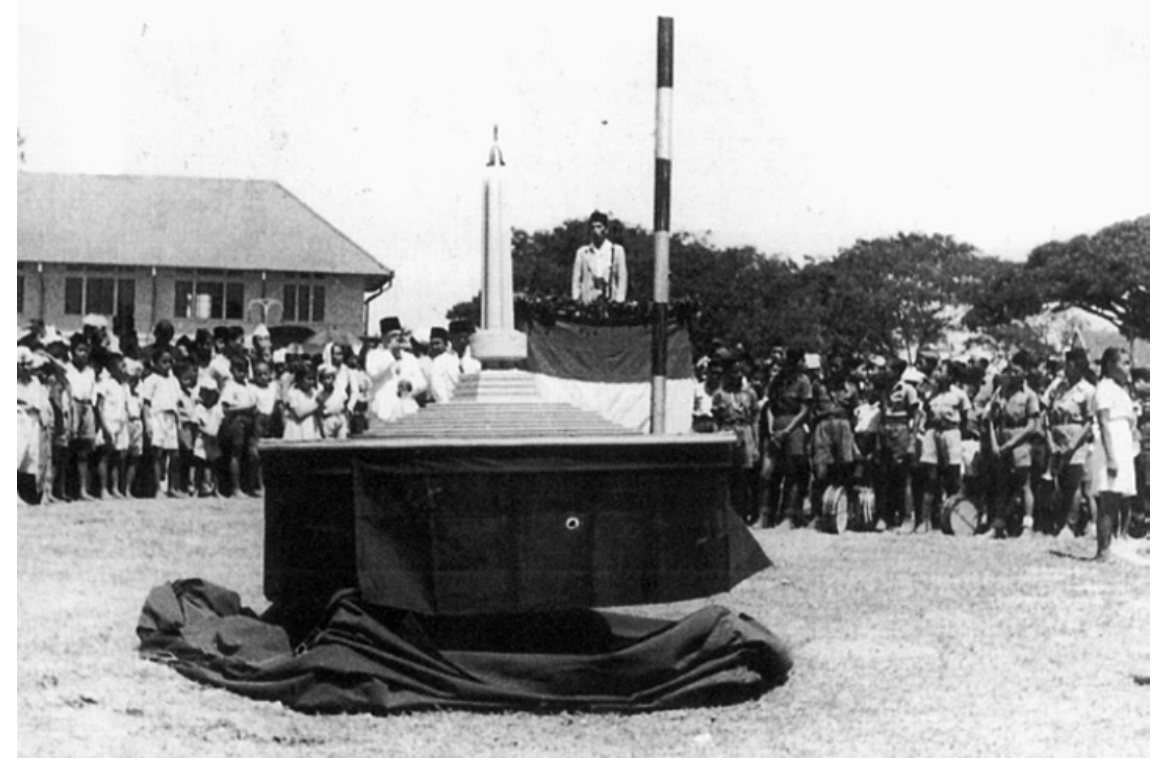

FIGURE 11.5 Laying of the foundation stone of the Independence monument in Malang, 17 August 1946

SOURCE: VAN SCHAIK (1996:122; COURTESY OF STUDIO MALANG, MALANG)

having to construct a new monument. ${ }^{4}$ However, I believe this attempt to transform the existing monument and thereby create a new orientation in the town did not succeed, because the structure hidden under the Dutch flag and crown still belonged to the Indonesians.

It is easy to imagine that the erection of the Independence monument in the centre of the Alun-Alun Bunder fired the courageous imagination of the Malang youth with the belief that, as long as the monument remained standing, they would never be defeated even though the Dutch army was equipped with the most up-to-date guns. With such a firm belief entrenched, the only recourse available to Dutch forces to break the spirit of the Malang resistance was to demolish the monument, which they did on 23 December 1948. The Dutch destruction of the Indonesian monument was in a way their 'revenge' for the Indonesian burning of the town hall on the same alun-alun as part of the Republican scorched-earth strategy of July 1947. The destruction of the

4 For an image of it, see Van Schaik (1996:122). 
monument on the Alun-Alun Bunder marked the peak of the symbolic battle between the Dutch soldiers and the Indonesian inhabitants of Malang. For some years, the burning down of the municipal buildings and the destruction of the Independence monument left the Alun-Alun Bunder a no-man's-land, a deserted area disfigured by ruined buildings.

The period after the recognition of Indonesian sovereignty emerged as the most crucial time in the history of Indonesia. Five years after the Proclamation of Independence, Indonesia faced tremendous difficulties in every aspect of life. The erection of the new monument was greeted warmly by the local community as it seemed to symbolize the reassertion of Indonesian rights, which had tended to fade. The Japanese occupation and the War of Independence had engendered many social, economic, political, and security problems. The long war had brought the people suffering and hardship, hitting housing and jobs particularly hard (Pewarta Soerabaia 24-3-1952). In Malang the depths to which the Aloon-Aloon had sunk was demonstrated by the presence of prostitutes on the Aloon-Aloon. Under the banyan trees in the centre of the AloonAloon, a host of prostitutes would sell themselves at night (Pewarta Soerabaia 24-3-1952). According to research undertaken later in 1968, these prostitutes were those who charged the lowest prices (between 50 and 100 Rupiah) (Survey sekitar 1970:29). Their clients risked contracting syphilis or gonorrhoea. The prostitutes' trade also challenged the mosque located on the western edge of the alun-alun. Bambungan (squatters) who occupied the area or simply wandered around there were another indication of how the Aloon-Aloon had fallen in people's estimation.

Although the Aloon-Aloon was used as a 'cattle market', as people referred to the streetwalkers' area at night, during the day it was used as an ordinary market. On the southern side, what remained of the burned out house of the former Assistent-Resident was occupied by many traders. The place was called Pasar Atoom (Atom Market) in imitation of the name of a big market in Surabaya. Perhaps the traders in Malang secretly hoped that one day their market might be as big as that in Surabaya. Flower-sellers occupied the western part of the alun-alun, stretching from in front of the church to the mosque. In fact, until 196os the alun-alun was the biggest outlet for flowers in Malang.

The presence of the traders on the alun-alun was a continuation of the old tradition of the popular rule over the alun-alun. In the colonial period, the ordinary people had had to fight against the colonial authority for control of the alun-alun. After Independence they still had to fight against the municipal government. In 1952, the traders in Pasar Atoom were expelled because the government decided to renovate the former Assistent-Resident's house and turn it into offices. Eventually, this plan fell through (Pewarta Soerabaia 
16-7-1952). In fact, in September $195^{2}$ an intercity bus stop was built on the area (Pewarta Soerabaia 1-9-1952). The bus stop only served to reinforce the impression that the Aloon-Aloon was no longer a sacred place.

\section{The Era of Politics}

The euphoria of freedom was more than just a time to display slogans splashed on the walls of public buildings, stopping public transportation by force and getting in without paying a cent, or for yelling such heroic words as "Life or Death". It was also the time to take action by joining organizations or political parties, something which would have seemed beyond people's wildest dreams in the colonial period. Independence signalled the arrival of grassroots politics, which no authority could suppress. In this period, open spaces were essential because politics was public and without an open public space, politics could not have been public. Open spaces within the town essentially meant the alun-alun. Hence the alun-alun became a crucial element in the political euphoria in the 1950s and 196os.

In Malang, the Aloon-Aloon was designated the chosen open space where competing ideologies could battle each other for dominance, as it was the place which belonged to the local people. It was only in the 1950 s that an attempt was made to breathe new life into the area. On 1 May 1950, around the time of the anniversary of the Partai Komunis Indonesia (PKI, Indonesian Communist Party), a group of party members erected a large, twice life-size statue on the plinth of the original monument, which had remained intact. Even though it was not a permanent statue it seems to have elicited a response from the authorities. A month later, on 9 June 1950, a Liberty Monument Committee was established to organize the erection of a permanent monument (Suwardono and Rosmiayah 1996:24). The committee worked hard for three years to raise the money to rebuild the damaged monument, a task that was finally completed in the middle of 1953 (Pewarta Soerabaia 16-5-1953). Local newspapers such as Pewarta Soerabaia reported the physical details of the monument in their headlines. The description in Pewarta Soerabaia on 16 May 1953 indicates that it did not differ greatly from the original design of 1946. It featured six bamboo spears tied together in an unbreakable bond.

The Java Post, of 19 May 1953 published a poem by R. Dirman Sasmokoadi to celebrate the monument:

Malang Monument of Liberty

Who on this earth is not proud of 


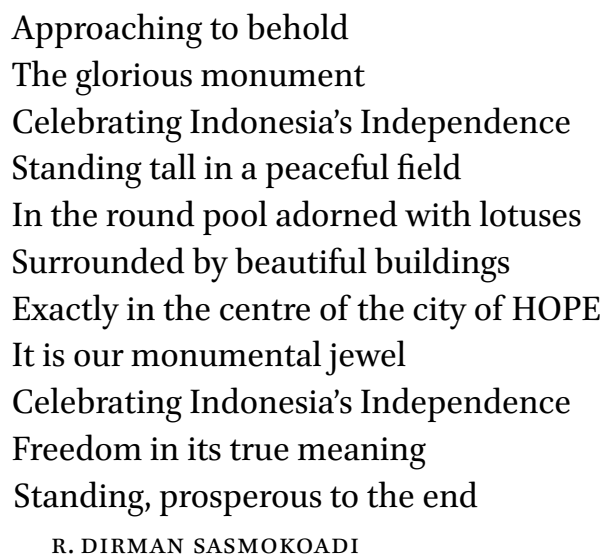

On 20 May 1953, a ceremony was held to mark the unveiling of the monument by President Sukarno. It was witnessed by thousands of people, but their presence was probably motivated more by the arrival of the president, than purely by any thoughts about the liberty monument. The person of Sukarno was more charismatic and more symbolic of Indonesia's Independence than the monument. The Java Post of 21 May 1953 reported: "At 4:45 the president began to deliver his speech in front of the people. There were no posters by the people." The lack of placards can be read as the absence of protesters. It was proof that this time the people in Malang were looking forward to greeting President Sukarno. Later, in the years in which the president was involved in conflicts with the military and various political parties, his arrival was often greeted by large demonstrations. This time, it seemed, the president had come to confirm the undisputed victory of the Indonesian people and the role of Malang in the struggle against the Dutch.

On the eve of the 1955 general election when parties were struggling for support, the political atmosphere intensified enormously. For example, on 29 January 1955, a mass organization operating under the banner of the old Javanese doctrine Djawo Dwipo held a parade called 'Ngruwat Pusoko Djowo' (Purifying the Heirlooms of Java) (Java Post 28-1-1955, 29-1-1955). The parade commenced at Jodipan Wetan, proceeded via various streets through to the Aloon-Aloon and ended again at Jodipan. Actually, the main focal point of the parade was the Aloon-Aloon as the ritual of Djawo Dwipo was centred there. When the parade reached the Aloon-Aloon, people gathered in the centre of the square, where they sang a religious song dedicated to Djawo Dwipo and danced. The ritual was to declare 'Penuntun Kawruh Kasempurnaning Gesang' (Leaders towards Knowledge of the Perfection of Life). The organization later claimed that the event had been attended by almost a million people, 986,000 
to be exact. In fact, only a few thousand out of the total of less than one million citizens of Malang bothered to turn up (Java Post 28-1-1955). Political rhetoric had conjured up a nonsensical reality. The Djawo Dwipo organization, which represented abangan (non-orthodox Muslim) power in Malang, wanted to reempower the alun-alun as a place for the people.

Another leader who attempted to use the alun-alun of Malang was Bung Tomo, who had led the Republican troops against the British in the Battle of Surabaya in November 1945. On 24 September 1955, he visited the Aloon-Aloon as the spokesperson for the campaign of the Indonesian Party. His exclaiming "Allahu Akbar" (God is great) and his highly emotive appeal might have galvanized Surabaya but did not win much support in Malang (Java Post 25-9-1955). His campaign attracted only a few people and he failed to gain significant numbers of votes in the general election. Amazingly, in 1955 there were no Islamic parties making use of the Aloon-Aloon to propagate their programmes and ideology. 5 The outcome of the 1955 general election proved that Malang was dominated by abangan people; the Indonesian Communist Party emerged as the local victor. The liberty monument on the Alun-Alun Bunder became a dominant symbol of the town of Malang. For any charity event, small pins bearing a picture of the monument were often sold to raise money. In fact, on 14 July 1970, it became the central element in the coat-of-arms of Malang, replacing the old symbol of an eagle.

\section{Conclusion}

In the past hundred years, the two alun-alun of Malang have been the focus of processes of signification and spontaneous actions. History has revealed how the people in Malang have attempted to retain their control of these spaces. Each alun-alun exuded a different significance for the local people. The indigenous residents claimed their rights to the Aloon-Aloon by a silent invasion long before Indonesia gained its independence and Malang was freed from Dutch domination. This was different in the case of the Alun-Alun Bunder. Created as an elite area under Dutch colonialism, which revived briefly during the Dutch attempt to regain control after Independence was proclaimed, the Alun-Alun Bunder continued to be the focus of official symbolic representation of power. After the transfer of sovereignty, it became a symbol of the

5 In fact, Islamic groups did attempt to use the Aloon-Aloon after the 1955 general election. On 10 March 1957, thousands of Muslims gathered there to protest against Sukarno's concept of a National Board (Pewarta Soerabaia 11-3-1957). 
power of a liberated nation and urban community. The control of the symbolism of this public space was constantly contested and associated with repeated periods of struggle.

\section{References}

Berdoeri, Tjamboek (2004). Indonesia dalem api dan bara. Jakarta: Elkasa.

Bogaers, Erica and Peter de Ruijter (1986). 'Ir. Thomas Karsten and Indonesian town planning, 1915-1940', in: Peter J.M. Nas (ed.), The Indonesian city: Studies in urban development and planning, pp. 71-88. Dordrecht and Cinnaminson: Foris Publications. [Verhandelingen KITLV 117.]

Coté, Joost (2014). 'Thomas Karsten's Indonesia: Modernity and the end of Europe, 1914-1945, Bijdragen tot de Taal-, Land-en Volkenkunde 170:66-98.

Hall, Peter (1993). Cities of tomorrow: An intellectual history of urban planning and design in the twentieth century. Cambridge: Blackwell.

Handinoto and Paulus H. Soehargo (1996). Perkembangan kota dan arsitektur kolonial Belanda di Malang. Yogyakarta: ANDI.

Jaarverslag 1940 (1941). Jaarverslag 1940 Stadsgemeente Malang. [Malang: Stadsgemeente.]

Kota Malang (1954). 40 Tahun kota Malang. Malang: Dewan Pemerintah Kota Malang. Kotapradja Malang (1964). Kotapradja Malang 50 tahun. Malang: Kotapradja Malang. Moertono, Soemarsaid (1985). Negara dan usaha bina-negara di Jawa masa lampau: Studi tentang masa Mataram II, abad XVI sampai XIX. Jakarta: Yayasan Obor Indonesia.

Nas, Peter J.M. (1986). 'Introduction: A general view on the Indonesian town', in: Peter J.M. Nas (ed.), The Indonesian city: Studies in urban development and planning, pp. 1-17. Dordrecht: Foris. [Verhandelingen KITLV 117.]

Schaik, A. van (1996). Malang: Beeld van een stad. Purmerend: Asia Maior.

Soekiman, Djoko (1996). Kebudayaan Indis dan gaya hidup masyarakat pendukungnya di Jawa (abad XVIII sampai medio abad XX). Yogyakarta: Yayasan Bentang Budaya, Yayasan Adikarya Ikapi and Ford Foundation.

Stadsgemeente Malang (1939). Stadsgemeente Malang 1914-1939. [Malang: Stadsgemeente.]

Surjomihardjo, Abdurrachman (2000). Kota Yogyakarta 1880-1930: Sejarah perkembangan sosial. Yogyakarta: Yayasan Untuk Indonesia.

Survey sekitar (1970). 'Survey sekitar beberapa motif dan efek serta pertimbanganpertimbangan pokok bagaimana cara menanggulangi tuna susila di masyarakat daerah Kotamadya Malang'. [Malang]: Djurusan Pendidikan Sosial IKIP Malang. [Unpublished manuscript.] 
Suwardono and Supiyati Rosmiayah (1996). Monografi sejarah kota Malang. Malang: Sigma Media.

Wiryomartono, A. Bagus P. (1995). Seni bangunan dan seni binakota di Indonesia: Kajian mengenai konsep, struktur, dan elemen fisik kota sejak peradaban Hindu-Buddha, Islam hingga sekarang. Jakarta: Gramedia Pustaka Utama. 